\title{
Life-threatening haemolysis induced by henna in a Sudanese child with glucose-6-phosphate dehydrogenase deficiency
}

\author{
Abdelmoneim Kheir ', Israa Gaber ${ }^{2}$, Sara Gafer ${ }^{2}$ and Wisal Ahmed ${ }^{2}$
}

\section{Introduction}

Glucose-6-phosphate dehydrogenase (G6PD) deficiency is the most common enzymopathy in humans affecting about 400 million people worldwide $(1,2)$. It is an X-linked recessive inborn error of metabolism which can result in haemolysis on exposure to a number of triggers, such as some infections, and certain medicines and foods. The Mediterranean mutation is the most common variant of the enzyme deficiency and is often associated with favism (3). Severe haemolytic episodes may result after contact with oxidants (4).

Henna, obtained from the crushed leaves of Lawsonia alba, has been used for centuries to dye the skin, hair and nails in many countries in south-east Asia and the Middle East (5). The application of henna has resulted in life-threatening episodes of haemolytic anaemia in individuals with a genetic deficiency in G6PD activity $(6,7)$.

We report on a 6-year-old boy, previously undiagnosed with G6PD deficiency, who developed life-threatening haemolysis after application of henna to his skin. This is the first report of henna-induced haemolytic anaemia in Sudan. Written informed consent was obtained from the father of the child for publication of this case report and any accompanying images.

A 6-year-old boy was brought by his parents to Soba University Hospital on 26 March 2015 with a two-day history of shortness of breath, headache and yellow discolouration of the sclera. There had been a change in his urine colour which was tea-like. This child was previously very well, however, his mother reported that henna had been applied to his hands and feet as part of a kindergarten graduation ceremony 3 days prior to admission. Similar symptoms had developed at the age of 2 years when henna was applied to his skin on the occasion of his circumcision but they did not seek any medical advice at the time. Apart from this, his past history was uneventful. There was no past history of blood transfusion or drug ingestion and no family history of a similar condition.

Physical examination revealed an extremely pale child with henna applied to his hands and feet (Figures 1 and 2). He was irritable with slight jaundice. His pulse rate was 125 beats/min., respiratory rate 30 breaths/min., temperature $37.3^{\circ} \mathrm{C}$, oxygen saturation $99 \%$ in room air and blood pressure normal $(100 / 70 \mathrm{mmHg})$. Clinical examination also revealed gallop rhythm and a short systolic murmur (haemic) on the left sternal border. All these symptoms and signs were suggestive of an acute haemolytic process.

Laboratory investigations showed haemoglobin of $4 \mathrm{~g} / \mathrm{dL}$, haematocrit of $13.1 \%$, reticulocyte count of $5.1 \%$, white cell count of $18.2 \times 10^{9} / \mathrm{L}$ and platelet count of $3592 \times 10^{9} / \mathrm{L}$ Peripheral smear showed mild hypochromia with anisocytosis and nucleated red blood cells. Blood film for malaria was negative and direct Coomb test was negative. Urine microscopy showed few pus cells, no red blood cells and bilirubin (++). A urine test for haemoglobin was not done as it was not available in our laboratory. Liver function test revealed a total serum bilirubin of $51.3 \mathrm{Umol} / \mathrm{L}$ and direct bilirubin of $5.13 \mathrm{Umol} / \mathrm{L}$; the rest of the liver function tests were normal. Renal function tests showed no derangement with serum urea of $12.5 \mathrm{mmol} / \mathrm{L}$, creatinine $44.21 \mathrm{Umol} / \mathrm{L}$ sodium $136 \mathrm{mmol} / \mathrm{L}$ and potassium of $4.2 \mathrm{mmol} / \mathrm{L}$.

A presumptive diagnosis of acute haemolysis due to G6PD deficiency was made and the child received 1 blood transfusion and folic acid after which he recovered fully. Six weeks later a blood sample was sent abroad to Jordan for G6PD assay by kinetic determination. It showed a low level of G6PD of $3.1 \mathrm{U} / \mathrm{g}$ (normal range 4.50-13.50 U/g), confirming his G6PD deficiency. The child was discharged home in good health after having been counselled regarding the condition and given a list of drugs and food items to avoid including nitrofurantoin, nalidixic acid, sulfamethoxazole and fava beans.

\section{Discussion}

The use of L. alba (henna) for medicinal and cosmetic purposes is part of ancient 


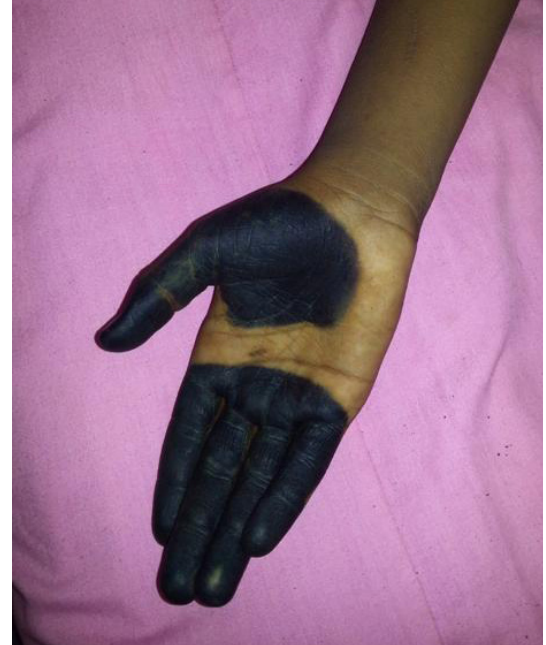

Figure 1 Henna application to the hand of the 6-year-old patient with hennainduced haemolysis

and modern cultures and traditions of North Africa and Asia. In some countries, it is used in ceremonial and social events, such as weddings and circumcisions, where henna is applied to the skin to create various patterns (7).

The active dye ingredient in henna, lawsone (2-hydroxy-1,4-naphthoquinone) has been implicated as a cause of henna-induced haemolytic anaemia because of its structural similarity to other ortho-substituted 1,4-naphthoquinones, such as menadione, which are known to induce oxidative injury in red blood cells (8). Henna extract, or lawsone, were found to induce severe haemolytic anaemia in various animal models after exposure of the skin or ingestion. This reaction is associated with oxidative damage to erythrocytes (5).

There are few reports of life-threatening haemolysis in G6PD-deficient patients due to henna application; most of the cases reported were young infants

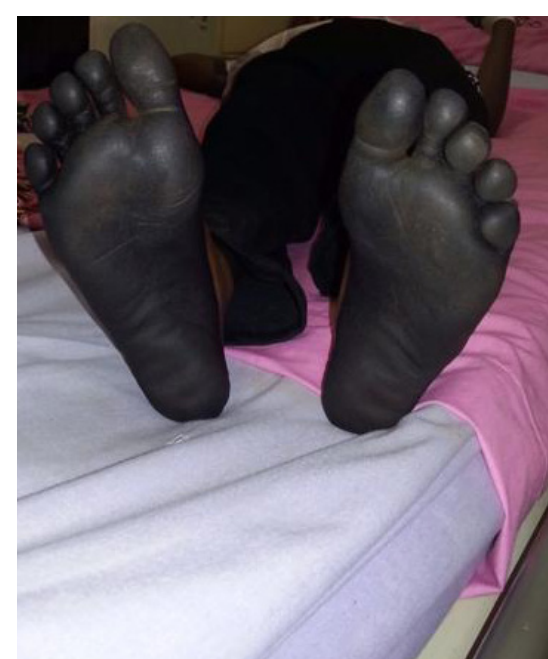

Figure 2 Henna application to the feet of the 6 -year-old patient with hennainduced haemolysis

or neonates. Soker et al. reported the oldest case, an 11-year-old boy with henna-induced haemolysis from Turkey (9). This G6PD-deficient patient had henna applied to the whole body to treat psoriatic skin lesions. Our case was a 6-year-old boy who had 2 episodes of haemolysis, the first at the age of 2 years when henna was applied to his skin on the occasion of his circumcision, but no treatment was required at that time. This is hard to explain but the amount of henna applied may have been small; lawsone is reported to cause haemolysis in a dose-dependent manner, as evidenced by decreased levels of haematocrit and haemoglobin and by histopathological changes in the spleen, liver and kidney (10).

Raupp et al. collected 4 cases over 1 year in the United Arab Emirates, suggesting the potential of henna to cause life-threatening acute haemolysis in G6PD-deficient children (6). Their cases included 1 neonate, 1 infant who died despite blood transfusion and 2 preschool children. Devecioliu and colleagues from Turkey reported a 27-day-old boy who developed haemolytic anaemia and acute renal failure following extensive topical application of henna (11).

Intravascular haemolysis of various causes can result in acute tubular necrosis due to haemoglobinuria leading to acute renal failure (12). Our case showed no derangement in his renal function, which might because of his early presentation and degree of haemolysis. In our case, liver function tests revealed a total serum bilirubin of $51.3 \mathrm{Umol} / \mathrm{L}$ and direct bilirubin of $5.13 \mathrm{Umol} / \mathrm{L}$. This is an expected finding as the destruction of red blood cells is characterized by increased unconjugated bilirubin; liberated haemoglobin is converted into unconjugated bilirubin in the spleen or may be bound in the plasma by haptoglobin (13).

This report highlights the lifethreatening risk of henna to cause acute haemolysis in G6PD-deficient children. The use of henna in many occasions, including graduation ceremonies, circumcision and weddings, is widespread in Sudan but the exact incidence of G6PD deficiency is unknown. However there are likely many children, such as our case, with undiagnosed G6PD deficiency. Therefore, the use of henna should be discouraged in infants in general and in G6PD-deficient individuals of any age. Additionally, public health education and universal G6PD screening are warranted to prevent this potentially lethal haemolytic crisis.

\section{Funding: None.}

Competing interests: None declared.

\section{References}

1. Mehta A, Mason PJ, Vulliamy TJ.Glucose-6-phosphate dehydrogenase deficiency. Baillieres Best Pract Res Clin Haematol. 2000;13(1):21-38. PMID: 10916676

2. Beutler E. G6PDdeficiency. Blood. 1994;84(11):3613-36. PMID: 7949118
3. Noori-Daloii MR, Najafi L, Ganji SM, Hajebrahimi Z, Sanati $\mathrm{MH}$. Molecular identification of mutations in G6PD gene in patients with favism in Iran. J Physiol Biochem. 2004;60:273-7. PMID: 15957246 
4. Kaplan M, Hammerman C. Understanding and preventing severe neonatal hyperbilirubinemia: Is bilirubin neurotoxicity really a concern in the developed world. Clin Perinatol. 2004;31:555-75. PMID: 15325538

5. McMillan DC, Sarvate SD, Oatis JE Jr, Jollow DJ. Role of oxidant stress in lawsone-induced hemolytic anemia. Toxicol Sci. 2004;82(2):647-55. PMID: 15456924

6. Raupp P, Hassan JA, Varughese M, Kristiansson B. Henna causes life threatening haemolysis in glucose-6-phosphate dehydrogenase deficiency. Arch Dis Child. 2001;85:411-2. PMID:11668106

7. Zinkham WH, Oski FA. Henna: a potential cause of oxidative hemolysis and neonatal hyperbilirubinemia. Pediatrics. 1996;97:707-9. PMID: 8628611

8. Munday R, Fowke EA, Smith BL, Munday CM. Comparative toxicity of alkyl-1,4-naphthoquinones in rats: relationship to free radical production in vitro. Free Radic Biol Med. 1994;16:72531. PMID: 8070675
9. Soker M, Devecioglu C, Haspolat K, Kikicl B, Dogru O. Henna induced acute hemolysis in a G6PD-deficient patient: a case report. Int Pediatr. 2000;15:114-6.

10. Munday R, Smith BL, Munday CM. Comparative toxicity of 2-hydroxy-3-alkyl-1,4-naphthoquinones in rats. Chem Biol Interact. 1995;98:185-92. PMID: 8548857

11. Devecioğlu C, Katar S, Doğru O, Taş MA.. Henna-induced haemolytic anemia and acute renal failure. Turk J Pediatr. 2001;43:65-6. PMID: 11297162

12. Dukkipati R. Yang EH, Adler S, Vintch J. Acute kidney injury caused by intravascular hemolysis after mechanical thrombectomy. Nat Clin Pract Nephrol. 2009;5(2):112-6. PMID: 19092794

13. Dhaliwal G, Cornett PA, Tierney LM Jr. Hemolytic anemia. Am Fam Physician. 2004;69(11):2599-606. PMID: 15202694 